introduced with reported sensitivities varying between $60 \%$ and $80 \%{ }^{14}{ }^{15}$ More recently modifications have led to the use of multiple- and orthogonal-lead systems, ${ }^{34}$ with a reported sensitivity of $80 \% .^{3}$ Vector cardiographic analysis has been applied to the exercise test with the Frank system of three orthogonal leads ${ }^{16}$; this gives a sensitivity of $85^{\circ} \%$. These results are comparable with the findings of Simoons and Hugenholtz, who used computer averaging techniques and multivariate analysis of ST-segment data. ${ }^{17}$ Although vector cardiographic and computer analyses achieve good results, they require special expertise and equipment that is not usually available in most centres. Precordial surface mapping, on the other hand, may be performed with standard equipment, and no special training is needed to interpret the records.

In this study the orthogonal system and precordial surface mapping were compared using a treadmill and bicycle ergometer respectively. This introduced an extra variable, whose effect we tried to minimise as far as possible by using the same end-points for the period of exercise in each patient-that is, fatigue, dyspnoea, or chest pain. The similar maximum heart rates achieved in both tests to some extent provided objective evidence that the heart had been subjected to similar stresses on both occasions.

This investigation showed the sensitivity of surface mapping to be significantly superior to that of either the orthogonal system or a single chest lead. Clearly, by recording from 16 precordial positions areas of ischaemia that are inaccessible to the standard exercise ECG may be detected. In addition, the precordial surface map recorded after exercise adds an extra dimension to exercise electrocardiography by obtaining a measure of the area of ST-segment changes that are projected on to the front of the chest. Serial semi-quantitative observations may be made in each patient when evaluating medical and surgical treatment.
In this study we assessed a technique for recording the precordial exercise ECG that had a sensitivity of $95 \%$ when compared with the findings at coronary arteriography. The technique is therefore of value in patients presenting with chest pain and should reduce the need for angiography.

This work was supported in part by a grant from the British Heart Foundation. We are grateful to Professor J F Goodwin, Dr C M $\Rightarrow$ Oakley, and Dr D M Krikler for allowing us to study patients under $\stackrel{\mathscr{S}}{\stackrel{9}{2}}$ their care.

\section{References}

${ }^{1}$ Rosing, D R, Reicheck, N, and Perloff, J K, American Heart fournal, 1974, 87, 584 .

2 Sheffield, L T, Cardiovascular Clinics, 1975, 6, 93.

${ }^{3}$ Mason, R E, et al, Circulation, 1967, 36, 517.

${ }^{4}$ Frank, E, Circulation, 1956, 13, 737.

${ }^{5}$ Fox, K M, Selwyn, A P, and Shillingford, J P, British Heart fournal. OO In press.

${ }^{6}$ Bruce, R A, Annals of Clinical Research, 1971, 3, 323.

7 Scandinavian Committee on ECG Classification, Acta Medica Scandinavica, 1967, suppl No 481, p 1.

8 Reid, D S, Pellides, L J, and Shillingford, J P, British Heart fournal, ! $1971,33,370$.

9 Judkins, M P, Radiology, 1967, 89, 815.

10 Epstein, S E, et al, Circulation, 1967, 35, 1049

${ }^{11}$ Master, A M, and Jaffa, H L, fournal of the Mount Sinai Hospital, 1941, 7,629 .

${ }^{12}$ Fitzgibbon, G M, et al, Annals of Internal Medicine, 1971, 74, 509.

${ }^{13}$ Phibbs, B P, and Bucknells, L J, American Heart fournal, 1975, 90, 275.

${ }^{14}$ Roitman, D, Jones, W B, and Sheffield, L T, Annals of Internal Medicine, 1970, 72, 641.

${ }^{15}$ Martin, C M, and McConahay, D R, Circulation, 1972, 46, 956.

${ }_{16}$ Kilpatrick, D, Lancet, 1976, 2, 332.

17 Simoons, M L, and Hugenholtz, P G, Circulation, 1977, 56, 552.

\title{
Effects of propranolol and metoprolol on the peripheral circulation
}

\author{
P D MCSORLEY, D J WARREN
}

than metoprolol. Similar changes were seen in the hypertensive patients.

Propranolol should be used with care in patients with

\section{Summary and conclusions}

The effects of single doses of propranolol and metoprolol on skin temperature and skin and muscle blood flow were compared in 10 normal subjects and four patients with essential hypertension. In normal subjects the mean skin temperature fell by $1.300 .62 \mathrm{C} 90$ minutes after $80 \mathrm{mg}$ propranolol and $0 \cdot 15+0.05 \mathrm{C}$ after $100 \mathrm{mg}$ metoprolol. Skin blood flow and resting muscle blood flow were not affected by metoprolol but fell significantly after propranolol. Both drugs reduced post-exercise muscle hyperaemia, propranolol by more

\footnotetext{
Hypertension Laboratory, Department of Renal Medicine, University of Southampton, St Mary's Hospital, Portsmouth PO3 6AD

$P$ D MCSORLEY, MB, MRCP, lecturer in clinical pharmacology

D J WARREN, DPHIL, MRCP, consultant physician and senior lecturer in nephrology
}

\section{Introduction}

The importance of the cardioselectivity of beta-adrenergic neurone blocking drugs (beta-blockers) in relation to airways obstruction is well documented. ${ }^{1}$ It is less clear whether $\stackrel{0}{=}$ selectivity is an advantage in relation to other side effects of $\underset{\Phi}{+}$ beta-blockers. Cold hands in patients taking propranolol were 0 noted early" but not always reported in other studies. ${ }^{3}$ It has 0 been suggested' that Raynaud's phenomenon occurs in $59 \%$ of patients taking propranolol and $35^{\circ}$ " of patients taking atenolol, $\mathbb{\mathbb { D }}$ though the conduct of that study was questioned." Cold hands are more common during treatment with a cardioselective betablocker than placebo, ${ }^{6}$ but of greater clinical concern is the 8 report of peripheral gangrene in a patient receiving propranolol and in another taking the relatively cardioselective drug metoprolol.

We have measured skin temperature and skin and muscle blood flow after doses of propranolol and metoprolol to see 
whether cardioselectivity confers any advantage in the regulation of the peripheral circulation.

\section{Subjects and methods}

Ten normal male members of medical and laboratory staff and four patients with uncomplicated benign essential hypertension were studied. No cigarette smokers were included, and no subjects were taking hypotensive or other drugs. Skin temperature and skin and muscle blood flow were measured at rest and 90-110 minutes after single oral doses of propranolol $80 \mathrm{mg}$, metoprolol $100 \mathrm{mg}$, and placebo given in randomised double-blind fashion, repeat studies being carried out at intervals of not less than three days. Subjects were studied after acclimatisation for 20 minutes in a room with an ambient temperature of $23-24 \mathrm{C}$, the coefficient of variation of room temperature during any one study being less than $2 \%$. Skin temperature and skin and muscle blood flow were measured at rest, and muscle blood flow immediately after two minutes of bicycle exercise at $40 \%$ of maximum tolerated load $(75 \pm 8 \mathrm{~W})$.

Skin temperature was measured $6 \mathrm{~cm}$ above the lateral malleolus with a thermistor made up in a surface-measurement probe (Light Laboratories, Brighton) and connected through a Wheatstone bridge to a flatbed recorder giving a deflection of $1.2 \mathrm{~cm} /{ }^{\circ} \mathrm{C}$. Skin blood flow was measured $14 \mathrm{~cm}$ above the lateral malleolus on the anterior surface of the leg, and muscle blood flow in the quadriceps at midthigh level. Blood flows were measured after intradermal or intramuscular injection of $0 \cdot 1 \mathrm{ml}{ }^{133} \mathrm{Xe}(1 \mathrm{mCi} / \mathrm{ml})$ made up in normal saline (Radiochemical Centre, Amersham). The decay of radioactivity was displayed on a flatbed recorder, and flow calculated by standard formulae. The area injected is assumed to be homogenous with respect to blood flow and inert-gas solubility. On this basis local blood flow is calculated by the equation: blood flow $=100 \times \lambda \times 2 \cdot 3 \times \mathrm{D}$ $\mathrm{ml} / 100 \mathrm{~g} / \mathrm{min}$, where $\lambda$ is the tissue blood coefficient for ${ }^{133} \mathrm{Xe}(0 \cdot 7)$. The factor 2.3 converts natural to decade logarithms. $\mathrm{D}$ is the numerical value of the slope to the tangent of the logarithmic clearance curve $\left(2 \cdot 3 \times D=K\right.$ (conventional time constant) $=0 \cdot 693 / t \frac{1}{2}$ ). Blood flow was calculated from the initial rapid component of the isotope decay curve, since the slow late component is due to decay of ${ }^{133} \mathrm{Xc}$ in subcutaneous tissues. To exclude the possibility that diffusion of ${ }^{133} \mathrm{Xe}$ within the tissues might be responsible for a component of the decay curve, injections were made into tissues obtained post mortem. The reproducibility of the method was determined by measuring skin and muscle blood flow at approximately the same site on two separate occasions in 18 normal subjects at an interval of not less than three days.

Blood pressure was measured at frequent intervals in the equilibration period, during the 90 minutes after dosing, and at the end of bicycle exercise using an Arteriosonde (Kontron Instruments), and heart rate was determined by radial artery palpation.

\section{Results}

The correlation coefficients for duplicate measurements of skin blood flow in the 18 normal subjects was 0.91 , and for muscle blood flow $0 \cdot 89$. After injecting ${ }^{133} \mathrm{Xe}$ into dead tissue no appreciable decay was obtained when the counting conditions were identical with those used in normal living subjects.

Measurement of heart rate and blood pressure in the normal subjects showed that both at rest and at the end of bicycle exercise the heart rate was lower after beta-blocking drugs than after placebo (table).

Mean $(S D)$ heart rate and blood pressure $(B P)$ at rest and immediately after bicycle exercise in normal and hypertensive subjects given placebo, propranolol, and metoprolol

\begin{tabular}{|c|c|c|c|c|c|c|}
\hline & \multicolumn{2}{|c|}{ Placebo } & \multicolumn{2}{|c|}{ Propranolol } & \multicolumn{2}{|c|}{ Metoprolol } \\
\hline & $\begin{array}{l}\text { At } \\
\text { rest }\end{array}$ & $\begin{array}{c}\text { After } \\
\text { exercise }\end{array}$ & $\begin{array}{l}\text { At } \\
\text { rest }\end{array}$ & $\begin{array}{c}\text { After } \\
\text { exercise }\end{array}$ & $\begin{array}{l}\text { At } \\
\text { rest }\end{array}$ & $\begin{array}{l}\text { After } \\
\text { exercise }\end{array}$ \\
\hline \multicolumn{7}{|c|}{ Normal subjects } \\
\hline $\begin{array}{l}\text { Heart rate } / \mathrm{min} \\
\text { Systolic } \mathrm{BP}(\mathrm{mm} \mathrm{Hg}) \\
\text { Diastolic BP }(\mathrm{mm} \mathrm{Hg})\end{array}$ & $\mid \begin{array}{r}68 \pm 6 \\
129 \pm 9 \\
82 \pm 6\end{array}$ & $\left|\begin{array}{c}109 \pm 11 \\
168 \pm 12 \\
76 \div 5\end{array}\right|$ & $\mid \begin{array}{r}59 \pm 4 \\
127 \pm 8 \\
81: 6\end{array}$ & $\left|\begin{array}{c}76+7 \\
150 \\
87 \pm 4\end{array}\right|$ & $\mid \begin{array}{r}63 \div 4 \\
130 \div 8 \\
83 \pm 6\end{array}$ & $\mid \begin{array}{rl}81 & 8 \\
156 & 10 \\
79 & 4\end{array}$ \\
\hline \multicolumn{7}{|c|}{ Hypertensive patients } \\
\hline $\begin{array}{l}\text { Heart rate } / \mathrm{min} \\
\text { Systolic BP }(\mathrm{mm} \mathrm{Hg}) \\
\text { Diastolic BP }(\mathrm{mm} \mathrm{Hg})\end{array}$ & $\mid \begin{array}{c}84 \pm 7 \\
184 \pm 12 \\
106 \pm 10\end{array}$ & $\left|\begin{array}{l:l}116 & 11 \\
216 & 14 \\
104 & 9\end{array}\right|$ & $\mid \begin{array}{c}66+5 \\
176+11 \\
108+8\end{array}$ & $\left|\begin{array}{c:c}72 & 6 \\
188 & 10 \\
118 \pm 6\end{array}\right|$ & $\left|\begin{array}{c:c}69 & 5 \\
179 & 12 \\
107 \pm 7\end{array}\right|$ & $\mid \begin{array}{r}78 \\
192 \\
108\end{array}$ \\
\hline
\end{tabular}

There was no difference between the two drugs when heart rates at rest and at the end of bicycle exercise were compared, suggesting that similar degrees of beta-blockade were achieved. By the end of bicycle exercise systolic but not diastolic blood pressure had risen significantly $(\mathrm{P}<0.05)$ in the placebo group. Mean blood pressure after exercise was slightly but significantly lower after beta-blocking drugs than placebo. Qualitatively similar changes were seen in the hypertensive patients, with the exception that diastolic blood pressure at the end of exercise was significantly $(\mathbf{P}<0.05)$ higher after propranolol than after placebo or metoprolol.

Skin temperature was $31.60 \pm \mathrm{SD} 0.35^{\circ} \mathrm{C}$ after placebo in normal subjects and fell insignificantly by $0.15^{\circ} \mathrm{C}$ after metoprolol but by $1.30^{\circ} \mathrm{C}$ after propranolol $(\mathrm{P}<0.05)$ (figure). There were no significant differences between room temperatures when different treatment periods were compared. Mean skin temperature in the hypertensive patients showed similar trends, falling by $0 \cdot 1{ }^{\circ} \mathrm{C}$ after metoprolol and by $1.35^{\circ} \mathrm{C}$ after propranolol $(\mathrm{P}<0 \cdot 05)$.

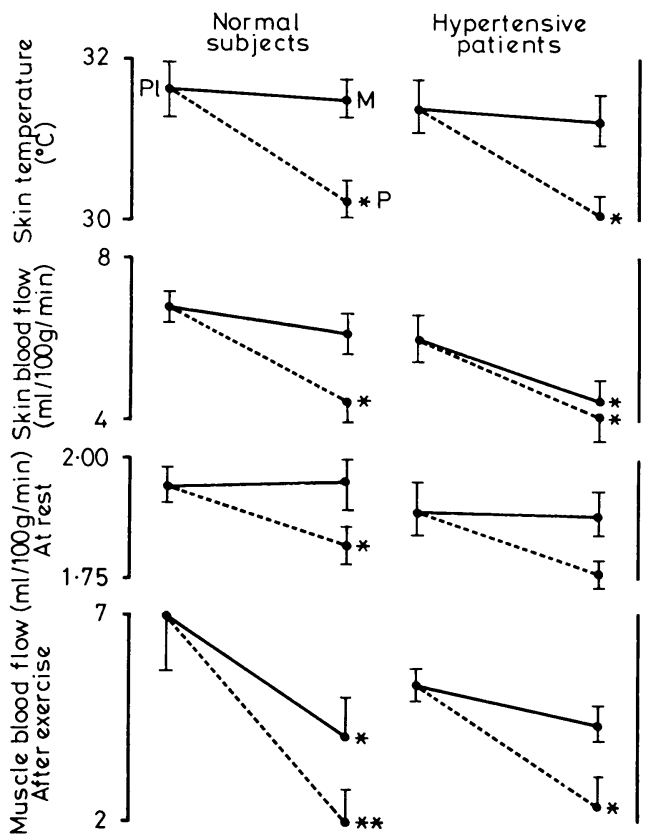

Mean $( \pm S D)$ skin temperature and skin and muscle blood flow in 10 normal subjects and four patients with essential hypertension. Results after metoprolol ( $M$ solid lines) and propranolol ( $\mathrm{P}$, dashed lines) compared with results after placebo $(P 1) .{ }^{*} P<0 \cdot 05$. ${ }^{* *} P<0 \cdot 01$.

Skin blood flow was not reduced appreciably by metoprolol (figure) but fell by $32 \%$ after propranolol, there being a significant difference in response to the two drugs $(P<0.05)$. In contrast, metoprolol and propranolol caused a similar fall in skin blood flow in the four hypertensive subjects. Muscle blood flow in the normal subjects at rest was unchanged after metoprolol but reduced by $20 \%$ after propranolol $(P<0.05)$. In the hypertensive patients at rest muscle blood flow showed similar differences in response to beta-blockers. Muscle blood flow at the end of bicycle exercise was $7 \cdot 0 \pm \mathrm{SD} 1.2 \mathrm{ml} / 100 \mathrm{~g} / \mathrm{min}$ $(\mathrm{P}<0.05)$ and was reduced by $74 \%$ after propranolol $(\mathrm{P}<0.01)$ and $42 \%$ after metoprolol $(\mathrm{P}<0.05)$ in normal subjects. Post-exercise muscle blood flow in the hypertensive patients was $28 \%$ lower than in normal subjects, falling by $15 \%$ after metoprolol (NS) and $54 \%$ after propranolol $(\mathrm{P}<0.05)$.

\section{Discussion}

Adrenaline causes muscle vasodilatation by an agonist effect on beta $a_{2}$-adrenergic receptors. After one intravenous dose of propranolol this effect is lost and adrenaline then causes an increase in peripheral resistance and blood pressure, thought to be due to unopposed stimulation of peripheral alpha-receptors. The vasodilatation produced by adrenaline is largely preserved after a single dose of metoprolol. ${ }^{9}$ Similar differences in the 
effects of metoprolol and propranolol on the peripheral circulation occur after long-term oral dosing. ${ }^{10}$ Our findings show differences between the effects of metoprolol and propranolol on skin temperature, skin blood flow, and muscle blood flow both at rest and after exercise in normal subjects and support, by direct measurement of tissue blood flow, the hypothesis that cardioselectivity may be an important property of beta-blockers if these are to be given to patients with established peripheral vascular disease. Our results, in common with those on airways resistance, ${ }^{1}$ show that cardioselectivity is not an absolute property and that metoprolol has a significant effect in reducing post-exercise muscle hyperaemia. This effect, however, is much less pronounced than that of propranolol, which also reduces skin temperature, skin blood flow, and resting muscle blood flow.

Our results in four patients with benign essential hypertension showed similar differences between the two beta-blockers, with the exception that metoprolol also caused a significant reduction in skin blood flow.

These results, taken in conjunction with clinical reports of peripheral gangrene in hypertensive patients being treated with beta-blockers, ${ }^{7}$ suggest that metoprolol has important advantages over propranolol in its effect on the peripheral circulation. Although technical factors limited our observations on exercise to post-exercise hyperaemia, we believe that the differences we have shown between the effects of the two drugs are significant. Further studies on the effects of these and other beta-blocking drugs on muscle blood flow during graded physical exercise are clearly needed.

We are grateful to our general-practitioner colleagues who allowed us to study their patients, and to our subjects for their forbearance.

\section{References}

${ }^{1}$ Skinner, C, Gaddie, J, and Palmer, K N V, British Medical fournal, 1976, 1, 504 .

2 Zacharias, F J, Postgraduate Medical fournal, 1971, 47, suppl, p 75.

3 Prichard, B N C, Boakes, A J, and Day, G, Postgraduate Medical fournal, 1971, 47, suppl, p 84 .

${ }^{4}$ Marshall, A J, Roberts, C J C, and Barritt, D W, British Medical fournal, 1976, 1, 1498.

${ }^{5}$ Marsden, C W, and Hayliss, P F C, British Medical fournal, 1976, 3, 176.

${ }^{6}$ Sheriff, H M R, Howard, O, and Warren, D J, Acta Therapeutica, 1978, 4, 51.

7 Vale, J A, Pette, S J, and Price, T M, Lancet, 1977, 2, 412

${ }^{8}$ Vale, J A, and Jefferys, D B, Lancet, 1978, 1, 1216.

9 Johnsson, G, Acta Pharmacologica et Toxicologica, 1975, 36, suppl 5, p 59.

10 Van Herwaarden, C L A, et al, British Medical fournal, 1977, 2, 1029.

\title{
Liver enzyme concentrations as measure of possible infectivity in chronic asymptomatic carriers of hepatitis $B$
}

\author{
J A J BARBARA, VALERIE MIJOVIC, T E CLEGHORN， R S TEDDER， MOYA BRIGGS
}

British Medical fournal, 1978, 2, 1600-1602

\section{Summary and conclusions}

Fifty-two British-born blood donors who were chronic carriers of hepatitis $B$ surface antigen (HBsAg) were tested for the presence of hepatitis $B$ e antigen (HBeAg) and antibody to HBeAg by an immunoradiometric assay. The presence of HBeAg was closely associated with a slight rise in serum liver enzyme concentrations, a high HBsAg titre, and male sex.

We suggest that the finding of persistently raised serum liver enzyme concentrations in an asymptomatic HBsAg carrier might be useful as a likely indicator of HBeAg and high infectivity.

\section{Introduction}

Hepatitis B surface antigen ( $\mathrm{HBsAg}$ ), antibody to $\mathrm{HBsAg}$, hepatitis B core antigen, and antibody to core are well-

\footnotetext{
North London Blood Transfusion Centre, Edgware, Middlesex HA8 9BD

J A J BARBARA, MA, PHD, principal microbiologist

VALERIE MIJOVIC, BSC, PHD, principal biochemist

T E CLEGHORN, FRCP, FRCPATH, director

Department of Virology, Middlesex Hospital Medical School, London W1P 7LD

R S TEDDER, MA, MRCP, Wellcome research fellow

MOYA BRIGGS, BSC, research assistant
}

established markers of past or present infection by hepatitis B virus. The e-antigen ( $\mathrm{HBeAg}$ ) system described by Magnius ${ }^{1}$ has aroused considerable clinical interest with the finding of an association between $\mathrm{HBeAg}$ and high infectivity in vertical ${ }^{2}$ and horizontal ${ }^{3}$ transmission.

When an undiagnosed carrier of HBsAg is discovered in a community-particularly a carrier working in medical care-the question naturally arises whether that person is likely to be infectious. One of the most useful indices of potential infectivity, ${ }^{45}$ but one that is not easy to assay in a routine laboratory investigation, is the e antigen. The presence of $\mathrm{HBcAg}$ has been used as an indicator of liver disease, ${ }^{6}$ and among carriers those with chronic liver disease appear to be the most infectious. ${ }^{7}$ In this study we have correlated the presence of $\mathrm{HBeAg}$ in chronic asymptomatic carriers with raised serum liver enzyme concentrations in an attempt to assess indirectly the usefulness of liver enzyme monitoring as an indicator of high infectivity.

\section{Subjects and methods}

Blood Donors-British-born blood donors were screened for HBsAg by reverse passive haemagglutination (RPHA; Hepatest, Wellcome Reagents Ltd). Samples for confirmation were obtained from all who were HBsAg-positive. The first and second, or subsequent, specimens were titrated in parallel; donors were excluded from the study if they had a greater than twofold difference in $\mathrm{HBsAg}$ titres over a minimum of three months. So that we could make comparisons with results from a transfusion centre abroad that used countermigration electrophoresis to detect $\mathrm{HBsAg}$, we selected only RPHA positive donors who were also positive by this technique for inclusion in the series. The ad or ay subtype was determined by immunoradiometric assay. ${ }^{8}$

Detection of $\mathrm{HBe} \mathrm{Ag}$ and antibody to $\mathrm{HBe} \mathrm{Ag}($ anti-HBe $-\mathrm{HBeAg}$ and 